\title{
The future of Technology Enhanced Learning (TEL) is in the hands of the anonymous, grey non-descript mid-level professional manager
}

\author{
Tony Murphy ${ }^{1}$ \\ University of Lancaster \\ (Received October 2016; final version received October 2016)
}

\begin{abstract}
Much of the research into the implementation of TEL has centred on teaching approaches and the change (or not) in the role of the academic, which is reflective of the importance of the academic to what takes place in a Higher Education Institute (HEI). Technology enhanced learning (TEL), however, poses a considerable challenge to how the Higher Education (HE) sector operates, as it has done with numerous other sectors. Typically, technology confronts existing practices and boundaries. For HEIs, TEL has accelerated the move away from the discipline-based academics as being at the centre of the education process and replaced them with students. This displacement of the academic for the student has been complemented by changing approaches to teaching, (the growth of network learning for example) and the introduction of new work practices from the private sector in the guise of new managerialism. With the academic's role reduced from controller to that of participant, the space left is being filled by client-focused mid-level professional managers. Distinct from academic managers, mid-level professional managers are situated between academics and senior management, which is a key position for the implementation of TEL at a time when its future rests on bridging the gap between the bottom up initiatives of the past and the institute-wide initiatives of the future. This discussion piece reflects on the changing role of the academic in a new managerialist TEL HE sector and argues for the overdue recognition of the importance of the mid-level professional manager to the future of TEL.
\end{abstract}

\section{Introduction}

This discussion paper emerged as an aside to a literature review that is part a doctoral thesis looking at the management of blended learning courses in higher education in Ireland. Much of the recent literature on management in HEIs has been dominated by the debate on collegiality and new managerialism (Clegg \& McAuley, 2005; Ramirez \& Tiplic, 2013; Stensaker, Välimaa, Henkel, \& Sarrico, 2012), and the literature review for the thesis took place within that context. In conducting the literature review, it emerged that with idea of the advent of Technology Enhanced Learning (TEL) and new managerialism, the role of the academic in HE is changing which appears to be a particularly interesting development when juxtaposed against the rising influence of the non-academic professional manager in HE. What this discussion paper seeks to do is to consider how the roles of

\footnotetext{
${ }^{1}$ Corresponding author. Email: t.murphy1@lancaster.ac.uk
}

Irish Journal of Technology Enhanced Learning Ireland, 2016. (C) 2016 T. Murphy. The Irish Journal of Technology Enhanced Learning Ireland is the journal of the Irish Learning Technology Association, an Irish-based professional and scholarly society and membership organisation. (CRO\# 520231) http://www.ilta.ie/. This is an Open Access article distributed under the terms of the Creative Commons Attribution 4.0 International License (http://creativecommons.org/licenses/by/4.0/), allowing third parties to copy and redistribute the material in any medium or format and to remix, transform, and build upon the material for any purpose, even commercially, provided the original work is properly cited and states its license. 
both the academic and the professional middle manager are changing in light of the influence that both TEL and new managerialism in HE. Moreover, it seeks to ask what these changes might mean for academics in the future as technology becomes more incorporated into teaching practices in HE.

\section{Helping the academic}

There has been considerable research into what TEL means for the academic and how best to help transition the academic into the TEL world. Much has been written about how, for example, academic staff may find considerable demands on their time as a result of TEL (Chao, Saj, \& Hamilton, 2010; Graham, Woodfield, \& Harrison, 2012; Gregory \& Lodge, 2015; Njenga \& Fourie, 2010) and may need to be compensated or incentivised to embrace TEL (Hanson, 2009; Porter, Graham, Spring, \& Welch, 2014). It is unusual to come across a research piece on TEL that does not have as one of its recommendations the need to train and develop academic staff in TEL and reinforce their existing role with increased support.

The argument has also been made that, with the impact of TEL, academics need to defend their role as central to the teaching and learning process by protecting their ownership of the development process (Davis \& Fill, 2007; Georgouli, Skalkidis, \& Guerreiro, 2008) and taking responsibility for driving TEL initiatives (Porter et al., 2014). Concern has been expressed with regard to the possible displacement of staff from their academic selves as a result of the opportunities offered by TEL (Hanson, 2009) and that, as a result, there is a need to protect the sanctity of independent scholarship. Also, there is a sense that academics need to be protected from encroachment on their space by other professional by ensuring that support for academics to engage with technology exists only on their terms and when they want it (Davis \& Fill, 2007). The assumption appears to be that the best way to approach the change and opportunities offered by TEL is to spend considerable time, effort and money loading up the academic with all the knowledge and skill they need not only to function in the TEL world but also retain their control of the teaching process.

\section{Technology changes the way HEIs operate}

However, technology, and most specifically the Internet, has had a dramatic effect on processes involved in teaching and learning, as it has done in a number of other sectors. TEL in the form of digital teaching and learning, eLearning, blended learning or online education has had a disruptive effect on the sector and given HE an opportunity to reflect, thereby presenting the chance to take an alternative look at many of the age-old assumptions about HE (Christenson, 2011). Rossiter (2007) takes that reflection a step further by claiming that sustainable and appreciated online education will require radically different strategies and processes than those currently employed in HE. To look at how teaching and learning is designed, developed and delivered, Bass (2012) highlights the merits of team-based design, while Soars (2013), Vasser, (2013) and Bates (2014) have each expounded on the idea that online education will demand a collaborative effort from, among others, instructional designers, educational developers, graphic designers, project managers, subject matter experts, voice over specialists and embedded librarians. Bass (2012) highlighted the kind of challenge that such a collaborative approach poses to the traditional authority of the academic, while the divisions of labour significance of an e-learning policy was also noted by de Freitas and Oliver (2005). In terms of faculty, Folkers (2005) notes that online education can involve a redistribution of power which challenges the authority of the academic. Bass (2012) puts it more dramatically when stating that "the power of innovation in the co-curriculum and flexible learning, particularly afforded by the internet are making colleges and universities run headlong into their own structures, into the way we do business" (p. 24).

As well as blurring traditional professional relationships, TEL challenges the norms, structures, processes, hierarchy, views, perspective and understanding of the HEI (Jones and O'Shea, 2004). TEL's need to be formalised and specified (Oliver, 2012) means that online education demands a level of transparency (Soars, 2013) and introduces an almost accountability by the back door that 
those who are delivering education were not previously subjected too. Online education also raises legal issues--copyright and intellectual property--that also have previously not needed to be addressed (Jones and O'Shea, 2004). These forces, together with the emergence of open social learning create pressures on models of educational provision at all stages of education "from childhood into workplace learning" (Buckingham and Ferguson, 2012, p. 8).

\subsection{Technologies challenge to teaching}

How specifically is TEL challenging the process of teaching? Coomaraswamy (2014) argues that advances in Information and Communication Technologies (ICT) are driving a major change in HE from instructional paradigm to learning paradigm. Technologies have moved from being merely supportive of learning to actually changing how learning takes place and how the learner interprets learning (Säljö, 2010). Garrison (2011) echoes these thoughts by claiming that HEIs have recognised a need to move away from passive lectures and that technology is simply the catalyst to make that move possible. For Bass (2012), the formal curriculum is being squeezed by the power of experiential learning and th.8e potential of informal learning. In other sectors, ICT has afforded the opportunity for the consumer to move to become a producer or at least a co-producer (Humphreys \& Grayson, 2008), with the term 'user generated content' becoming almost ubiquitous. Education is no different, as ICT has allowed the learner to become a producer of knowledge as much as a consumer (Cerratto-Pargman, Järvelä, \& Milrad, 2012). While Laurillard (2009) looked to existing educational theories to challenge digital technologies to deliver on a more enhanced learning experience, she argues that technology is facilitating a move away from teacher-focused to learner-focused activities associated with constructivism and social learning. It would appear that TEL and a social learning paradigm are working hand-in-hand to remove academics from the centre of the teaching process and replace them with the student.

\section{New Managerialism}

The advent of new managerialism into the HE sector is another development that undermines the idea that the academic retains central control of the teaching and learning process. A management ideology based on neo-liberal principles (Carvalho \& Santiago, 2010; Deem \& Brehony, 2005; V. Meek, Goedegebuure, Santiago, \& Carvalho, 2010), new managerialism is realised operationally with practices from the corporate world (Carvalho \& Santiago, 2010; Deem \& Brehony, 2005) that include quality assurance, downsizing and outsourcing, budget diversification, privatisation, performance appraisal and benchmarking (V. Meek et al., 2010). There has been a change in the makeup of professional and academic staff in HE. .In most four-year colleges in the U.S, "the average number of faculty and staff per administrator declined by roughly 40 percent between 1990 and 2012" (Desrochers and

Kirshstein, 2014 p. 3). The introduction of these practices has had an impact on how an academic functions. The academic enjoys less freedom and autonomy in an environment that is becoming more structured, monitored (Kolsaker, 2008), reviewed and measured (Hedley, 2010; Teelken, 2012) against such factors as value for money (Hedley, 2010) and client satisfaction (V. Meek et al., 2010). While these practices may not be a result of TEL, they are contributing, along with TEL, to the displacement of the academic as the central controlling figure in course development and delivery.

\section{The Need for a New Manager}

Rethinking the conceptual approach to teaching and learning in HE as a result of the opportunities of TEL (Christensen, Horn, Caldera, \& Soares, 2011; Marshall, 2012; Salmon, 2005), while adjusting to the onset of new managerialism in HE, is seen as relocating the academic away from the traditional central and controlling role in teaching and learning. If that is the case, then a vacuum has emerged that will inevitably be filled. For Garrison (2011), the response to the changes brought on by TEL 


\section{T. Murphy}

should be to tackle strategic planning, infrastructure and leadership issues if HE is to take ownership of the innovation. This idea of a new type of manager or leader is echoed by Jones and O'Shea (2004), whereas Jameson (2013) has gone as far as to call for a fifth age of educational technology research dedicated to e-leadership. Stepping into the void to take on the mantel of e-leader or emanager are the mid-level professional managers, who are distinct from academic managers (Bacon, 2009) in that they perform generalist roles and situationally are more likely to identify with the institution than any specific discipline. Goolnick (2012) argues that middle professional managers are using various methods to promote the characteristics of new managerialism. Whoever is responsible for embedding TEL into a HEI, whether they are agents for new managerialism or not, will have to pick apart and gain an understanding of the challenges and issues highlighted above while functioning in an increasingly new managerialist HE sector.

\subsection{What does the mid-level professional manager do?}

Not an awful lot is known about mid-level professional managers (De Boer, Goedegebuure, \& Meek, 2010; Hedley, 2010). It is debatable as to whether or not they are a distinct group within a HEI (Hedley, 2010; Trowler, 2010), and, if they are, what they do (De Boer et al., 2010; Rudhumbu, 2015). In the absence of research, one way of suggesting the typical tasks mid-level professional managers are doing is to recap on the issues raised by TEL above. These managers could be facilitating cross-function and cross-discipline collaboration and ensuring that there is a consistency offered in the delivery of digital teaching and learning. They could be managing the outsourcing of tasks to individuals and organisations separate to the HEI or even separate to the HE sector. There is also the management of the training and development of academic staff in TEL, the project management of the development of asynchronous content for online courses and the effort to ensure that online content is cognisant of the legal requirements imposed by copyright law and intellectual property rights. Allowing for student feedback and student contributions as co-producers to be embedded into course development and delivery is another task. If academics are to be compensated and incentivised to participate in TEL, it will be the role of the mid-level professional manager to get approval for the resourcing of that compensation, while convincing the financial powers of the HEI that TEL is a worthwhile investment by providing cost/benefit analysis and risk assessment. Utilising the tools to convince stakeholders that value for money is being achieved is only one of the many new managerialist activities to be facilitated by the mid-level professional manager; ensuring that quality assurance guidelines are drawn up and met is another as is the monitoring of performance.

When it comes to TEL, there is an argument to suggest that the academic, or even the academic manager, lacks both the skill base and the inclination to take on such challenges. Carrying out these tasks will inevitably bring the mid-level professional manager into the realms of curriculum design and assessment strategy, where the academic retains an important but arguably no longer a central and controlling role. Rather, it could be argued that the role of the academic starts and ends with working with the other members of the development team to ensure the educational integrity behind TEL, which is much more of a mix of consultative and tutoring activities.

\subsection{The Downside to the Mid-Level Professional Manager}

Academics might question the business that a non-academic manager has in getting involved in assessment strategy and curriculum design. The argument being that when it comes to the activities of teaching and learning all other priorities take a back seat to the learning objectives and path to achieving those objectives as determined by the academic. Teaching and learning has always accepted other priorities along with the learning objectives, however. Commerciality, internal politics, the needs of industry, the strategic objectives of the HEI, the availability of resources all factor in how a course is developed and delivered. Such non-teaching priorities are multiplied with the inclusion of TEL in whatever format it takes. 
Pushing back against these non-academic priorities is the concept of academic freedom. According to the Irish Universities Act of 1997,

14 (2) A member of the academic staff of a university shall have the freedom, within the law, in his or her teaching, research and any other activities either in or outside the university, to question and test received wisdom, to put forward new ideas and to state controversy or unpopular opinions and shall not be disadvantaged, or subject to less favourable treatment by the university, for the exercise of that freedom.

Similarly, the Institutes of Technologies Act of 2006 states that

5 (2) A member of the academic staff of a college shall have the freedom, within the law, in his or her teaching, research and any other activities either in or outside the college, to question and test received wisdom, to put forward new ideas and to state controversial or unpopular opinions and shall not be disadvantaged, or subject to less favourable treatment by the college, for the exercise of that freedom

This freedom allows the academic to preserve an impartial and objective approach to teaching and learning, free of any non-educational influences. To deny academic freedom by supplanting the academic with a professional manager is to remove the primary protector of the purpose of any HEI, which is to provide for learning. The potential marginalisation of the academic and the rise of the mid-level professional manager as highlighted above endangers academic freedom and then, by consequence teaching and learning. If the academic is no longer central and controlling, how then can academic freedom be protected against the pressures of new managerialism?

\section{The Future}

While Goolnick (2012) highlighted the new managerialist tendencies of the mid-level professional manager, Clegg \& McAuley (2005) would argue that there is more complexity to the role. They point to the diversity of routes and locations into HE middle management as well as the diversity of motivations behind the actions of the middle manager. Trowler (2010) agrees, claiming the "the manager's professional identity and the discourses he or she draws on are dynamic and protean" (p. 205). While they might look to new managerialist ideology, mid-level professional managers will also draw on ideas that "flow from their disciplinary background as well as from an earlier humanist, collegial set of understandings of higher education" (Trowler, 2010, p. 204). It has been argued that mid-level managers have the potential to subtly influence different local strategies and institutional programmes, as they act as mediators who evaluate and dissolve tensions (Carvalho \& Santiago, 2010; Marini \& Reale, 2015) allowing for information to flow smoothly between departments and within the institution (Rudhumbu, 2015). It could be argued that these middle managers are perfectly placed within the organisation to influence academics and encourage commercial, new managerial activity (Trowler, 2010; Winter, 2009), while also addressing the issues of embedding TEL into a HEI and, at the same time preserving academic freedom over teaching and learning.

\section{Conclusion}

Whether or not the mid-level professional manager holds the key to the future of TEL in HE is debatable, but what is true is that the impact of technology on HE is not going to subside or dissipate. Similarly, new managerialism is not going away and is becoming even more entrenched in HE. With an appreciation of how TEL is changing the nature of teaching and learning and an understanding of what new managerialism can mean for process and operations in HE, the mid-level professional manager appears to be ideally positioned to guide the process of transitioning bottom-up to institutewide TEL initiatives. What then for the academic? To what extent will academics be able to retain a central and controlling role in teaching and learning? Even if new managerialism morphs into a form of neo-collegiality, as has been argued (Bacon, 2014; Burnes, Wend, \& By, 2014; Elton, 1995; 


\section{T. Murphy}

Rixom, 2011; Teelken, 2012), where broader more collective decision making is restored and a compromise is struck between the decentralised disciplines and centralised control, there will still be considerable challenges for academics - TEL will continue to require a collaborative, planned and structured approach, social and open learning will continue to raise the student voice and collective decision making for teaching and learning will increasingly involve non-academic professionals. Academics will no longer be able to continue to work as individuals but will have to see themselves as equal members of multi-skilled development teams as TEL becomes less distinct and more the new normal. To what extent academics are prepared to embrace this change and accept this new reality remains to be seen.

\section{References}

Bacon, E., (2009). Do professional managers have a profession: the specialist/generic distinction amongst higher education professional services staff. Perspectives: Policy and Practice in Higher Education, 13(1). doi:10.1080/13603100802597007.

Bacon, E. (2014). Neo-collegiality: Restoring academic engagement in the managerial university. London: The Leadership Foundation for Higher Education.

Bass, R., (2012). Disrupting Ourselves: The Problem of Learning in Higher Education. EDUCAUSE Review, March-April. http://er.educause.edu/ /media/files/article-downloads/erm1221.pdf

Buckingham Shum, S. \& Ferguson, R., (2012). Social Learning Analytics. Social Learning Analytics, 15(3), 3-26. http://www.ifets.info/journals/15_3/2.pdf.

Burnes, B., Wend, P., \& By, R. (2014). The changing face of English universities: reinventing collegiality for the twenty-first century. Studies in Higher Education, 39(6), 1-22. doi: 10.1080/03075079.2012.754858

Carvalho, T., \& Santiago, R. (2010). New Public Management and "Middle Management": How Do Deans Influence Institutional Policies? The Changing Dynamics of Higher Education Middle Management, 33, 165-196. doi:10.1007/978-90-481-9163-5

Cerratto-Pargman, T., Järvelä, S. M., \& Milrad, M. (2012). Designing Nordic technology-enhanced learning. Internet and Higher Education, 15(4), 227-230. doi: 10.1016/j.iheduc.2012.05.001

Chao, I. T., Saj, T., \& Hamilton, D. (2010). Using collaborative course development to achieve online course quality standards. The International Review of Research in Open and Distance Learning, 11(3), 106-126. doi: 10.19173/irrodl.v11i3.912

Christensen, C., Horn, M. B., Caldera, L., \& Soares, L. (2011). Disrupting College How Disruptive Innovation Can Deliver Quality and Affordability to Postsecondary Education. Innosight Institute: Center for American Progress. doi: 10.1306/74D70D8F-2B21-11D7-8648000102C1865D

Clegg, S., \& McAuley, J. (2005). Conceptualising middle management in higher education: a multifaceted discourse. Journal of Higher Education Policy and Management, 27, 19-34. doi: $10.1080 / 13600800500045786$

Coomaraswamy, U., (2014). Information and Communications Technology as a Change Agent for Higher Education. In S. Mishra (ed), ed. ICT Leadership in Higher Education: Selected readings. New Delhi: The Commonwealth Educational Media Centre for Asia. 
Davis, H. C., \& Fill, K. (2007). Embedding blended learning in a university's teaching culture: Experiences and reflections. British Journal of Educational Technology, 38(5), 817-828. doi: 10.1111/j.1467-8535.2007.00756.x

De Boer, H., Goedegebuure, L., \& Meek, V. L. (2010). The Changing Dynamics of Higher Education Middle Management. Higher Education Dynamics, 33, 83-102. doi: 10.1007/978-90-481-9163-5

de Freitas, S. \& Oliver, M., (2005). Does e-learning policy drive change in Higher Education?: A case study relating models of organisational change to e-learning implementation. Journal of Higher Education Policy and Management, 27(1), 81-95. doi: 10.1080/13600800500046255.

Deem, R., \& Brehony, K. J. (2005). Management as ideology: the case of "new managerialism" in higher education. Oxford Review of Education, 31(2), 217-235. doi: 10.1080/03054980500117827

Desrochers, D.M. \& Kirshstein, R., (2014). Labor Intensive or Labor Expensive? Changing Staffing and Compensation Patterns in Higher Education Overview Delta Cost Project Issue Brief, February. http://files.eric.ed.gov/fulltext/ED558470.pdf.

Elton, L. (1995). Task Differentiation in Universities: Towards a New Collegiality. Tertiary Education and Management, 2(2) 138-145.

Georgouli, K., Skalkidis, I., \& Guerreiro, P. (2008). A framework for adopting LMS to introduce elearning in a traditional course. Educational Technology and Society, 11(2), 227-240. http://www.ifets.info/journals/11_2/17.pdf

Graham, C. R., Woodfield, W., \& Harrison, J. B. (2012). A framework for institutional adoption and implementation of blended learning in higher education. Internet and Higher Education, 18, 4-14. doi: 10.1016/j.iheduc.2012.09.003

Garrison, D.R., (2011).E-Learning in the 21st Century: A Framework for Research and Practice. Oxford: Routledge.

Gregory, M. S.-J., \& Lodge, J. M. (2015). Academic workload: the silent barrier to the implementation of technology-enhanced learning strategies in higher education. Distance Education,36(2), 1-21. doi: 10.1080/01587919.2015.1055056

Hanson, J. (2009). Displaced but not replaced: the impact of e-learning on academic identities in higher education. Teaching in Higher Education, 14(5), 553-564. doi:10.1080/13562510903186774

Hedley, S. (2010). Managerialism in Irish Universities. Irish Journal of Legal Studies, 1(1), 117-141. http://ssrn.com/abstract=1654533

Humphreys, A. \& Grayson, K. (2008). the Intersecting Roles of Consumer and Producer: a Critical Perspective on Co-Production, Co-Creation and Prosumption. Sociology Compass, 2(2), 963-980. doi: 10.1111/j.1751-9020.2008.00112.x

Institutes of Technologies Act, Government of Ireland (2006).

Irish Universities Act, Government of Ireland, (1997).

Jones, N. \& O'Shea, J., (2004). Challenging hierarchies: The impact of e-learning. Higher Education, 48(3), 379-395. doi: doi:10.1023/B:HIGH.0000035560.32573.d0 


\section{T. Murphy}

Kolsaker, A. (2008). Academic professionalism in the managerialist era: a study of English universities. Studies in Higher Education, 33(5), 513-525. doi: 10.1080/03075070802372885

Laurillard, D. (2009). The Pedagogical Challenges to Collaborative Technologies. International Journal of Computer-Supported Collaborative Learning, 4(1), 5-20. doi: 10.1007/s11412-008-9056-2

Marini, G., \& Reale, E. (2015). How does collegiality survive managerially led universities? Evidence from a European Survey. European Journal of Higher Education. doi: $10.1080 / 21568235.2015 .1070676$

Marshall, S. (2012). E-learning and higher Education: understanding and supporting organisational change. Wellington: Ako Aotearoa National Centre for Tertiary Teaching Excellence.

Meek, V., Goedegebuure, L., Santiago, R., \& Carvalho, T. (2010). Introduction. The Changing Dynamics of Higher Education Middle Management, 33, 1-14. doi:10.1007/978-90-481-9163-5

Njenga, J. K., \& Fourie, L. C. H. (2010). The myths about e-learning in higher education. British Journal of Educational Technology, 41(2), 199-212. doi: 10.1111/j.1467-8535.2008.00910.x

Oliver, M., (2012). Technology and Change in Academic Practice. In P. Trowler, M. Saunders, \& V. Bamber, eds. Tribes and Territories in the 21st-Century: Rethinking the significance of disciplines in higher education. Oxford: Routledge.

Porter, W. W., Graham, C. R., Spring, K. a., \& Welch, K. R. (2014). Blended learning in higher education: Institutional adoption and implementation. Computers and Education, 75, 185-195. doi: 10.1016/j.compedu.2014.02.011

Ramirez, F. O., \& Tiplic, D. (2013). In pursuit of excellence? Discursive patterns in European higher education research. Higher Education, (123), 1-17. doi: 10.1007/s10734-013-9681-1

Rixom, A. (2011). Professionalisation and decision making in higher education management: new collegiality and academic change. (Unpublished doctoral thesis).University of Bath, Bath, U.K. http://opus.bath.ac.uk/28840/1/UnivBath_DBA_2011_A.E.Rixom.pdf

Rudhumbu, N. (2015). Managing Curriculum Change from the Middle: How Academic Middle Managers Enact Their Role in Higher Education. International Journal of Higher Education, 4(1), 106-119. doi: 10.5430/ijhe.v4n1p106

Säljö, R. (2010). Digital tools and challenges to institutional traditions of learning: Technologies, social memory and the performative nature of learning. Journal of Computer Assisted Learning, 26(1), 53-64. doe: /10.1111/j.1365-2729.2009.00341.x

Salmon, G. (2005). Flying not flapping: a strategic framework for e-learning and pedagogical innovation in higher education institutions. ALT-J, Research in Learning Technology, 13(3), 201-218. doi: 10.1080/09687760500376439

Stensaker, B., Välimaa, J., Henkel, M., \& Sarrico, C. (2012). Introduction: How Is Change in Higher Education Managed? In B. Stensaker, J. Välimaa, \& C. Sarrico (Eds.), Managing Reform in Universities. The Dynamics of Culture, Identity and Organizational Change, 1-16. Palgrave Macmillan. doi: 10.1057/9781137284297 
Teelken, C. (2012). Compliance or pragmatism: how do academics deal with managerialism in higher education? A comparative study in three countries. Studies in Higher Education, 37(3), 271-290. doi: $10.1080 / 03075079.2010 .511171$

Trowler, P. (2010). UK Higher Education: Captured by New Managerialist Ideology? The Changing Dynamics of Higher Education Middle Management, 33, 83-102. doi:10.1007/978-90-481-9163-5

Winter, R. (2009). Academic manager or managed academic? Academic identity schisms in higher education. Journal of Higher Education Policy and Management, 31(2), 121-131. doi: $10.1080 / 13600800902825835$ 